\title{
PREVALENCE OF CYTOMEGALOVIRUS INFECTION IN DIFFERENT PATIENT GROUPS OF A URBAN UNIVERSITY IN BRAZIL
}

\author{
José Hermógenes Rocco Suassuna, Leila Lopes Leite and \\ Lucia Helena Cavalheiro Villela
}

\begin{abstract}
This study sought for evidence of previous CMV infection in patients of a general bospital serving the low income population of Rio de Janeiro. An enzyme immunoassay was used to detect anti-CMV antibodies in 713 typical hospital patients classified into eight different groups. Positive tests were found in $87 \%$ of pregnant women, $85 \%$ of newborns, $61 \%$ of pediatric patients, $77 \%$ of adolescent patients, $81 \%$ of adult patients, $87 \%$ of dialysed transplant candidates, $89 \%$ of kidney donors, and $92 \%$ of patients after transplantation. Depending of the subgroup studied these results carry different meanings and necessitate different clinical approaches. The risk of congenital disease is probably low in view of the reduced number of pregnant women still susceptible to primary infection. The number of primary infections will also be low in transplant recipients. However, those still susceptible will almost certatnly acquire the infection from their donor. Propbylactic CMV matching in kidney transplantation is not a realistic approach due to the low probability of finding pairs of seronegative donors and recipients.
\end{abstract}

Key-words: Cytomegalovirus. Congenital infection. Immunosuppression. Transplantation.

Most adult individuals display serological evidence of past cytomegalovirus (CMV) infection but the great majority of these episodes are not clinically detected due to their benign nature. After the initial or primary infection, cytomegalovirus usually persists in the host in a latent, non-replicating state. In industrialized countries evidence of past infection is found in 40 to $85 \%$ of the adult population $^{3}$. These figures may vary under geographic and socioeconomic influences so that contact with CMV usually happens at an earlier age and may affect a greater proportion of the population in developing countries ${ }^{12}$.

Primary cytomegalovirus infection can be associated with significant morbidity and mortality in certain groups of individuals. Among these are included those with an immature immune system such as fetuses, those with immunodeficiency as a

Seção de Nefrologia eTransplante Renal and Laboratório de Imunologia Clínica. Hospital Universitário Pedro Ernesto. Universidade do Estado do Rio de Janeiro, Rio de Janeiro, RJ, Brasil

Address to: Dr. José H. R. Suassuna. R. Professor Manuel Ferreira 88/304, Gávea, 22451-030 Rio de Janeiro, RJ, Brasil. Recebido para publicação em 18/10/94. consequence of disease such as AIDS patients, and those with medically induced immunosuppression such as transplant recipients and cancer patients undergoing therapy'.

This study was designed to investigate the prevalence of CMV exposure in patients seen at a tertiary hospital serving the low income urban population of Rio de Janeiro. Our purpose was not to determine the prevalence of CMV infection in the general population. We sought instead to identify rates of exposure to CMV for typical in-hospital patients such as those undergoing medical procedures or treatments that pose a risk of cytomegalovirus transmission or reactivation.

\section{MATERIAL AND METHODS}

We surveyed all the tests for CMV serology from SUS (Sistema Unificado de Saúde Unified Health System) patients submitted to the clinical immunology laboratory of Hospital Universitário Pedro Ernesto between May 1990 and May 1991. A commercial enzyme immunoassay (Abbot CMV Total AB EIA Kit, USA) that detects all classes of immunoglobulins against cytomegalovirus was used throughout the study period. Patients 
Suassuna JHR, Leite LL, Villela LHC. Prevalence of cytomegalovirus infection in different patient groups of a urban university bospital in Brazil. Revista da Sociedade Brasileira de Medicina Tropical 28:105-108, abrjun, 1995.

with acute illness, already under immunosupressive therapy (except renal transplant recipients), those with mal:rnant diseases undergoing treatment, and those with confirmed or suspected AIDS were excluded.

We evaluated 713 patients, and classified them into eight different groups according to the source of the specimen: 1) pregnant women, 2) newborns, 3) pediatric patients between 1 and 11 years old, 4) adolescent patients between 11 and 18 years of age, 5) adult patients, 6) renal transplant candidates on dialysis, 7) live kidney donors, and 8) renal transplant patients with more than 6 months after surgery.

Some of the samples were submitted to the laboratory due to a clinical suspicion of CMV infection. It is possible that this procedure biased the study through the inclusion of patients with active infection. This selection bias was partially dealt with by only recording the first serum sample for each individual patient. Presumably these samples were taken at a time when seroconversion had not happened yet and, therefore, represent the prevalence for that particular group.

The prevalence rates between groups of interest were compared using the chi-square test. Significance was set at $\mathrm{p} \leq 0.05$.

\section{RESULTS}

We were able to collect samples from 54 pregnant patients and their offspring (one twin pregnancy). We also collected 40 additional samples from newborns transferred to our hospital and that had routine determination of CMV serology. Results for the group of paired mothers and newborns showed an almost exact correspondence ( $87.0 \%$ vs. $83.6 \%$ ) except for two newborns with absorbance reading in the undetermined zone (Table 1). The 40 other newborns also showed similar prevalence rates $(87.5 \%)$. All these results are not significantly different from each other $(p>$ 0.05).

Table 1- Pregnant mothers and newborns with positive cytomegalovirus serology.

\begin{tabular}{lccc} 
& & & \\
\hline Patient groups & $N^{2}$. tested & $\mathrm{N}^{2}$. positive & $\%$ \\
\hline Pregnant women & 54 & 47 & 87,0 \\
Offspring * & 55 & 46 & 83.6 \\
Transfered newborns & 40 & 35 & 87.5 \\
All newborns & 95 & 81 & 85.2 \\
\hline " p >0.05 for all groups & & & \\
** one twin pregnancy. & & &
\end{tabular}

Table 2 shows the results for three groups stratified by age. Prevalence rates increased according to the age strata the patient belonged to. They show a trend for acquisition of infection early in life. The rates however are significantly different only for pediatric patients in relation to the adult group ( $\mathrm{p}<$ 0.001 ).

Table 2- Hospital patients with positive cytomegalovimus serology.

\begin{tabular}{lrcc}
\hline Patient groups & $\mathbf{N}^{\alpha}$ tested & $N^{2}$ positive & $\%$ \\
\hline Pediatric patients & 118 & 72 & 61,0 \\
Adolescent patients & 39 & 30 & 76,9 \\
Adult patients & 121 & 98 & $81,0^{*}$ \\
\hline * $p<0.05$ - adult vs pediatric patients & &
\end{tabular}

" $p<0.05$ - adult vs pediatric patients.

Results for transplant patients and donors are depicted on Table 3. All three groups show higher prevalence rates than the group of general adult in-patients. However, when compared to those adult patients, the rates are significantly different only for patients which have undergone transplantation $(\mathrm{p}<0.05)$.

Table 3- Transplant patients and donors with evidence of previous cytomegalovirus infection.

\begin{tabular}{lccc}
\hline Patient groups & No. tested & No. positive & $\%^{*}$ \\
\hline Kidney donors & 75 & 67 & 89,3 \\
Renal transplant candidates & 146 & 127 & 87,0 \\
Renal transplant recipients & 65 & 60 & 92,3 \\
\hline
\end{tabular}

* $p>0.05$ for all groups.

\section{DISCUSSION}

Cytomegalic inclusion disease of the newborn is almost always the result of transplacental transmission during primary infection of the mother ${ }^{8}$. Children of mothers with reactivated $\mathrm{CMV}$ infection may acquire the virus but these episodes do not usually result in significant disease8. Therefore, knowledge about the rates of pregnant women still susceptible to primary infections in a given population are informative of the risk of CMV disease to their offspring. The lesser these rates are, the lower is the risk of CMV inclusion disease developing in the newborn ${ }^{5}$.

Our study, as well as previous studies in São Paulo and Rio de Janeiro ${ }^{4}$, have documented high rates of positive CMV serology in newborns suggesting that this was due to passive transfer of maternal IgG antibodies. Since we tested samples from pairs of pregnant women and their newborn children, the concordant results is in agreement with this proposition. 
Suassuna JHR, Leite LL, Villela LHC. Prevalence of cytomegalovirus infection in different patient groups of a urban university bospital in Brazil. Revista da Sociedade Brasileira de Medicina Tropical 28:105-108, abrjun, 1995.

For methodological reasons, we were not able to ascertain the exact age of the patients. Our results therefore must be taken with certain caution. Particularly in children's group (less than 11 years of age) the rates of patients with positive serology is expected to change dramatically early in life. Nevertheless, the data does serve to demonstrate that the individuals in the hospital population under study did acquire the infection early in life, displaying a high prevalence of past-contact with CMV. This pattern is characteristic of low income populations in developing countries ${ }^{72}$.

Our figures for adult patients and for organ donors are somewhat lower than in another study of CMV serology done on first time blood donors in the city of Rio de Janeiro. That report found a $97 \%$ prevalence rate of antiCMV antibodies ${ }^{14}$. This discrepancy may perhaps be ascribed to the different methodologies used in the two studies. However, $31 \%$ of those same blood donors also had serological evidence of contact with the hepatitis B virus ${ }^{14}$, suggesting that they were somehow selected to include high risk individuals.

The situation for organ (and blood) donors and their recipients is, in relation to the risk of developing clinically significant disease, diametrically opposite to that of pregnant mothers and their offspring. The viral multiplication of active infection is not a prerequisite to viral transmission. Latently infected transfused or transplanted cells can convey the virus should a non-infected susceptible individual receive the $\mathrm{m}^{3}$. These infections can evolve with a very severe clinical course, particularly in patients with immunological deficiency or immaturity ${ }^{3}$. In immunossupressed patients, the number of individuals at risk of developing aggressive primary infections is lower in populations with a high prevalence of seropositives. However, in those that are still susceptible, the risk of developing the disease rises with the prevalence of past-contact with CMV in the donor population.

We and other workers in Brazil have previously found lower rates of positive CMV serology in prospective kidney recipients ${ }^{6}{ }^{11}$. This was probably due to the less sensitive assays used at that time. The current results show that only $13 \%$ transplant candidates are still susceptible to primary CMV infection. As expected, kidney donors also had a very high prevalence of positive CMV serology. As a consequence, the few susceptible seronegative transplant recipients will have a 9 in 10 chance of being exposed to CMV carryed within the graft. Probably for this reason, post-renal transplant patients showed higher seroprevalence rates than other groups of individuals.

One last point that deserves comment is the recent proposition of allocating kidneys of CMV seronegative donors to CMV seronegative recipients (CMV matching) in order to prevent the occurrence of the more severe primary infections ${ }^{13}$. Our results suggest that this approach may not be practical to implement. From the data presented, one can infer that the probability of matching $\mathrm{CMV}$ seronegative kidney donors and recipients is under $1.4 \%$. Since, this will be done in addition to the more important immunological compatibility matching, this procedure will almost certainly severely reduce the chances of transplantation for CMV seronegative recipients. Other strategies such as immunization ${ }^{1}$ or drug prophylaxis ${ }^{2}$ will probably be more practical and effective for preventing CMV disease in seronegative kidney recipients ${ }^{10}$.

In conclusion, the population in the general hospital studied showed high rates of previous contact with CMV. These figures carry different meanings and necessitate different clinical approaches depending of the subgroup of patients the hospital physician is caring for.

\section{RESUMO}

Evidência de infecção passada por citomegalovirus foi pesquisada em pacientes de um bospital que serve à população de baixa renda na cidade do Rio de Janeiro. Realizou-se, com um imunoensaio enzimático, a pesquisa de anticorpos anti-CMV em 713 pacientes bospitalares, divididos em oito grupos. As taxas observadas foram $87 \%$ para grávidas, $85 \%$ para recém-natos, 61\% para pacientes pediátricos, $77 \%$ para adolescentes e $81 \%$ para adultos, $87 \%$ para pacientes em diálise, $89 \%$ para doadores de rim e $92 \%$ para pacientes após o transplante renal. Estes resultados têm diferentes significados e implicam em diferentes abordagens clinicas dependendo do subgrupo estudado. O risco de infecção congênita provavelmente é baixo devido no reduzido número de mulheres grávidas ainda susceptineis a infecçōes primárias. Pelo mesmo motivo, o nümero de infecções primárias deverá ser 
Suassuna JHR, Leite LL, Villela LHC. Prevalence of cytomegalovirus infection in different patient groups of a urban university bospital in Brazil. Revista da Sociedade Brasileira de Medicina Tropical 28:105-108, abrjun, 1995.

baixo nos transplantados renais. Entretanto, os soronegativos quase certamente adquirirão a infecção de seu doador e a compatibilização de doadores e receptores soronegativos não deverá ser uma abordagem realistica devido à baixa probabilidade de encontrar este tipo de par.

Palavras-chaves: Citomegalovírus. Infecção congênita. Imunosupressão. Transplante.

\section{REFERENCES}

1. Balfour Jr HH. Cytomegalovirus disease: can it be prevented? Annals of Internal Medicine 98: 544$546,1983$.

2. Balfour Jr HH, Chace BA, Stapleton JT, Simmons RL, Fryd DS. A randomized, placebo-controlled trial of oral acyclovir for the prevention of cytomegalovirus disease in recipients of renal allografts. The New England Journal of Medicine 320: 1381-1387, 1989.

3. Forbes BA. Acquisition of cytomegalovirus infection: an update. Clinical Microbiology Reviews 2: 204-216, 1989.

4. Nogueira RMR, Schatzmayr HG,Assis CER, Pinhão AT. Infecções pelo citomegalovírus e herpes simplex tipo 2.Amostragem em crianças de baixa idade no município do Rio de Janeiro. Clínica Pediátrica 10: 22-28, 1986.

5. Pannuti CS. Infecção por citomegalovírus. Pediatria 6: 144-153, 1984.

6. Pannuti CS, Vilas Boas LC, Amato Neto V, Angelo MJO, Sabbaga E. Detecção de anticorpos IgM nas infecções primárias e secundárias pelo citomegalovírus em pacientes submetidos a transplante renal. Revista do Instituto de Medicina Tropical de São Paulo 29:317-322, 1987.

7. Pannuti CS, Vilas-Boas LS, Angelo MJO, Carvalho RPS, Segre CM. Congenital cytomegalovirus infection. Occurrence in two socioeconomically distinct populations of a developing country.
Revista do Instituto de Medicina Tropical de São Paulo 27: 105-107, 1985.

8. Stagno S, Pass RF, Dworsky ME, Henderson RE, Moore EG, Walton PD, Alford Jr CA. Congenital cytomegalovirus infection: the relative importance of primary and recurrent maternal infections. The New England Journal of Medicine 306: 945-949, 1982.

9. Suassuna JHR, Machado RD. Diagnóstico das infecções por citomegalovírus em pacientes com deficiência imunológica. Revista da Associação Médica Brasileira 38: 33-47, 1992.

10. Suassuna JHR, Machado RD, Sampaio JS, Leite LL, Villela LHC, Ruzany ERM, Souza ERM, Moraes JRF. Active cytomegalovirus infection in hemodialysis patients receiving donor-specific blood transfusions under azathioprine coverage. Transplantation 56: 1552-1554, 1993.

11. Suassuna JHR, Ruzany F, Souza ERM, Sampaio JC, MAchado RD. Correlações clínico-virológicas nos quadros infecciosos causados por citomegalovírus em pacientes com transplantes renais. Revista de Microbiologia 21: 199-205, 1990.

12. Vial P, Torres-Pereyra J, Stagno S, Gonzáles F, Donoso E, Alford CA, Hirsch T, Rodríguez L. Estudio serologico para citomegalovirus, virus del herpes simple y de la rubeola, hepatitis B y Toxoplasma gondii en dos poblaciones de gestantes en Santiago, Chile. Boletin de la Oficina Sanitaria Panamericana 99: 528-536, 1985.

13. Williams PF, Wreghitt T, Joysey V, Evans DB, Calne RY. Cytomegalovirus matching in renal transplantation. The Lancet 2:569, 1988.

14. Yoshida CFT, Nogueira RMR, Mercadante LAC, Pinhão AT, Schatzmayr HG. Seroepidemiological survey of hepatitis $A$ and $B$, cytomegalovirus and herpes simplex type 2 in prime blood donors from Rio de Janeiro, Brazil. Revista de Microbiologia 18: 5-11, 1987. 